\title{
Non-Covalent Inhibitors of the 20S Proteasome
}

\author{
Carlos García-Echeverría*, Patricia Imbachª, Johannes Roesel, Peter Fuerst, Marc Lang, \\ Vito Guagnano, Maria Noorani, Johann Zimmermann, and Pascal Furet ${ }^{b}$
}

\begin{abstract}
Peptidomimetics have been commonly used as lead compounds to design inhibitors with high affinity and specificity for a particular enzyme. The discovery that a 2-aminobenzylstatine derivative originally designed to target an aspartyl protease was able to inhibit specifically and non-covalently the chymotrypsinlike activity of the $20 \mathrm{~S}$ proteasome represented a unique starting point for our medicinal chemistry endeavor for this target. Utilizing a structure-based design approach, we have been able to improve the potency of this new class of proteasome inhibitors without affecting its in vitro selectivity profile.
\end{abstract}

Keywords: Antitumor agents · Drug design · Enzyme inhibitors · Peptidomimetic

\section{Introduction}

The proteasome is a multifunctional ATPdependent proteolytic complex that is involved in the degradation of proteins implicated in critical intracellular regulatory cascades (e.g. mitotic cycle, cell growth and viability, antigen presentation or inflammatory response) [1]. The proteolytic activity of this enzyme occurs in a 700-kDa barrelshaped core structure known as the $20 \mathrm{~S}$ proteasome, which consists of four stacked rings arrayed in an $\alpha_{7} \beta_{7} \beta_{7} \alpha_{7}$ manner. Substrate specificity studies have revealed at least three distinct peptidase activities for the $20 \mathrm{~S}$ proteasome: chymotrypsin-like, trypsin-like, and peptidylglutamyl-peptide hydrolytic (PGPH) activities [2]. The hydrolytic sites function by a special mechanism. The initial attack on the peptide bonds is by the hydroxyl group of the N-terminal threonine of the catalytic $\beta$-subunit. After formation of the acyl-enzyme intermediate, the complex is hydrolyzed by the attack of a water molecule liberating the upstream product and the enzyme. The $20 \mathrm{~S}$ proteasome is therefore an $\mathrm{N}$-terminal threonine hydrolase.

*Correspondence: Dr. C. García-Echeverría Oncology Research

Novartis Pharma AG

$\mathrm{CH}-4002$ Basel

Tel.: +41616961094

Fax: +416169662 46

E-Mail: carlos.garcia-echeverria@pharma.novartis.com

aE-Mail: patricia.imbach@pharma.novartis.com

bE-Mail: pascal.furet@pharma.novartis.com
Our specific target in the search for novel cytotoxic and antiproliferative agents for cancer therapy is the chymotrypsin-like activity of the $20 \mathrm{~S}$ proteasome. Modulation of this enzymatic activity by $\beta$-subunitspecific proteasome inhibitors may convey an anti-tumor effect by induction of cell cycle arrest and apoptosis in tumor cells [3][4]. In this paper we describe the identification and initial optimization of noncovalent inhibitors of this therapeutic target.

\section{Results and Discussion}

Early natural and synthetic inhibitors of the $20 \mathrm{~S}$ proteasome were relatively nonspecific compounds and exerted their inhibitory activity by forming a covalent bond with the enzyme [5]. Classical warheads of serine proteases were utilized to block the catalytic threonine residue. The inherent drawbacks of these covalent inhibitors (e.g. non-target specific, high reactivity or instability) prompted us to search for alternative $\beta$-subunit-specific proteasome inhibitors.

To identify non-covalent inhibitors of the chymotrypsin-like activity of the $20 \mathrm{~S}$ proteasome we screened our in-house compound archive. Among the compounds identified, compound 1 (Table) was selected for further profiling. This 2-aminobenzylstatine derivative, which was originally synthesized to target the HIV-1 protease, inhibits the chymotrypsin-like activity of the $20 \mathrm{~S}$ proteasome with an $\mathrm{IC}_{50}$ value of $0.9 \mu \mathrm{M}$ and shows good selectivity over the trypsin-like and PGPH activities $\left(\mathrm{IC}_{50}>\right.$ $20 \mu \mathrm{M})$ [6][7]. Using the crystal structure of the yeast proteasome [8], a structural model of compound $\mathbf{1}$ bound to the chymotrypsin-like activity site of the human $20 \mathrm{~S}$ proteasome was developed to understand the structural basis of its inhibitory activity and to guide our medicinal chemistry optimization process [9].

The chymotrypsin-like site of the human $20 \mathrm{~S}$ proteasome has only two well-defined pockets (Fig. 1), and interactive molecular modeling was used to dock compound $\mathbf{1}$ in this catalytic site. A large number of complementary hydrophobic and hydrogen bond interactions between the inhibitor and the enzyme are observed in this model (Fig. 2). These interactions could account for the ability of compound $\mathbf{1}$ to inhibit the chymotrypsin-like activity site of the human $20 \mathrm{~S}$ proteasome without forming a covalent bond with the catalytic threonine residue.

A structure-based optimization approach was used to improve the $20 \mathrm{~S}$ proteasome chymotrypsin-like inhibitory activity of compound $\mathbf{1}$. According to our modular strategy, initial medicinal chemistry efforts were focused on the optimization of the N-terminal part of the 2-aminobenzylstatine scaffold [6][10].

The N-terminal benzyloxycarbonyl group was assumed to bind to an accessory pocket formed by the side chains of Tyr-33, Tyr-133 and Pro-131. In this particular region, the phenyl ring and the side chain of 
Table. Representative examples of 2-aminobenzylstatine derivatives and inhibition of the chymotrypsin-like activity of the $20 \mathrm{~S}$ proteasome ${ }^{\mathrm{a}}$<smiles>[R]N[C@H](C(=O)N[C@@H](Cc1ccccc1)[C@@H](O)[C@H](NCc1cccc([R2])c1)C(=O)N[C@H](C(=O)NCc1ccc(OC)cc1O)C(C)C)C(C)(C)C</smiles>

\begin{tabular}{|c|c|c|c|}
\hline Compound & $\mathbf{R}^{1}$ & $\mathbf{R}^{2}$ & $I C_{50}(\mu M)^{a}$ \\
\hline 1 & $\mathrm{CO}_{2} \mathrm{CH}_{2} \mathrm{Ph}$ & $4-\mathrm{OCH}_{3}$ & 0.9 \\
\hline 2 & $\mathrm{CO}_{2} \mathrm{CH}_{2}$ (1-naphthalene) & $4-\mathrm{OCH}_{3}$ & 2.0 \\
\hline 3 & $\mathrm{CO}_{2} \mathrm{CH}_{2} \mathrm{Ph}\left[3,5-\left(\mathrm{CH}_{3}\right)_{2}\right]$ & $4-\mathrm{OCH}_{3}$ & 1.1 \\
\hline 4 & $\mathrm{CO}_{2} \mathrm{CH}_{2} \mathrm{Ph}\left(3-\mathrm{NH}_{2}\right)$ & $4-\mathrm{OCH}_{3}$ & 0.6 \\
\hline 5 & $\mathrm{C}(\mathrm{O}) \mathrm{CH}_{2} \mathrm{CH}_{2} \mathrm{Ph}\left(3-\mathrm{NH}_{2}\right)$ & $4-\mathrm{OCH}_{3}$ & 0.6 \\
\hline 6 & $\mathrm{CO}_{2} \mathrm{CH}_{2} \mathrm{Ph}\left(3-\mathrm{CH}_{3}\right)$ & $4-\mathrm{OCH}_{3}$ & 0.5 \\
\hline 7 & $\mathrm{C}(\mathrm{O}) \mathrm{CH}_{2}(1-$ naphthalene $)$ & $4-\mathrm{OCH}_{3}$ & 0.1 \\
\hline 8 & $\mathrm{CO}_{2} \mathrm{CH}_{2} \mathrm{Ph}$ & $\mathrm{H}$ & $>20$ \\
\hline 9 & $\mathrm{CO}_{2} \mathrm{CH}_{2} \mathrm{Ph}$ & $2-\mathrm{OCH}_{3}$ & $>20$ \\
\hline 10 & $\mathrm{CO}_{2} \mathrm{CH}_{2} \mathrm{Ph}$ & $3-\mathrm{OCH}_{3}$ & 1.50 \\
\hline 11 & $\mathrm{CO}_{2} \mathrm{CH}_{2} \mathrm{Ph}$ & $2,4-\mathrm{OCH}_{3}$ & 1.60 \\
\hline 12 & $\mathrm{CO}_{2} \mathrm{CH}_{2} \mathrm{Ph}$ & $3,4-\mathrm{OCH}_{3}$ & 0.15 \\
\hline 13 & $\mathrm{CO}_{2} \mathrm{CH}_{2} \mathrm{Ph}$ & $3,5-\mathrm{OCH}_{3}$ & 0.19 \\
\hline 14 & $\mathrm{CO}_{2} \mathrm{CH}_{2} \mathrm{Ph}$ & $2,4,5-\mathrm{OCH}_{3}$ & 0.20 \\
\hline 15 & $\mathrm{CO}_{2} \mathrm{CH}_{2} \mathrm{Ph}$ & $2,3,4-\mathrm{OCH}_{3}$ & 0.10 \\
\hline 16 & $\mathrm{CO}_{2} \mathrm{CH}_{2} \mathrm{Ph}$ & $3,4,5-\mathrm{OCH}_{3}$ & 0.05 \\
\hline 17 & $\mathrm{C}(\mathrm{O}) \mathrm{CH}_{2}$ (1-naphthalene) & $3,4,5-\mathrm{OCH}_{3}$ & 0.007 \\
\hline
\end{tabular}

aThe $\mathrm{IC}_{50}$ value is the concentration of inhibitor at which the rate of the chymotrypsin-like activity of the $20 \mathrm{~S}$ proteasome catalyzed hydrolysis of the substrate Suc-Leu-Leu-Val-Tyr-AMC (AMC, 7-amido-4-methylcoumarin) is reduced at $50 \%$.

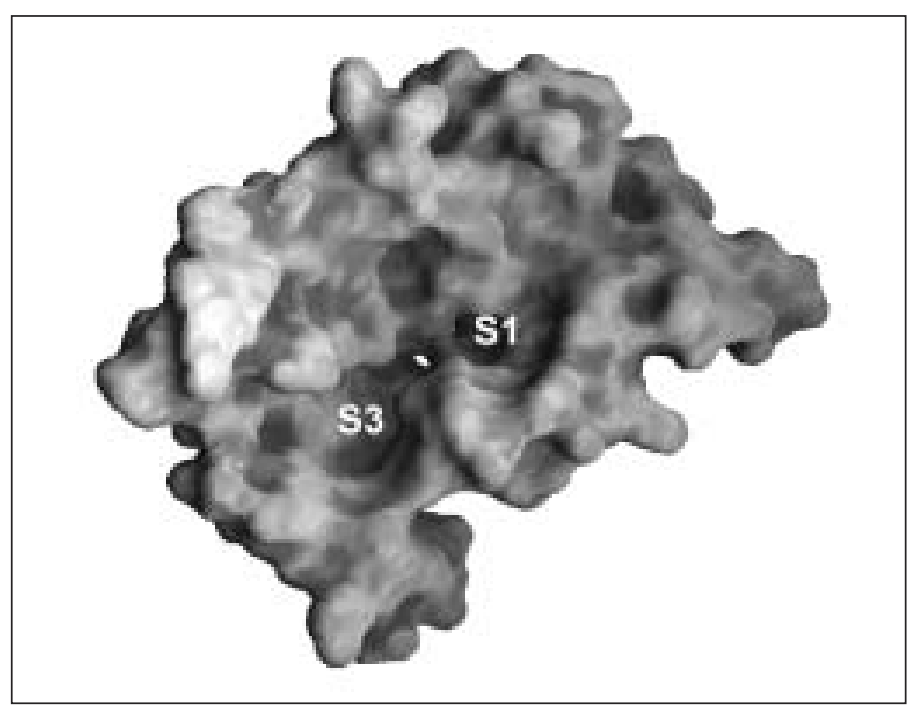

Fig. 1. Structural model of the chymotrypsin-like site of the human $20 \mathrm{~S}$ proteasome.

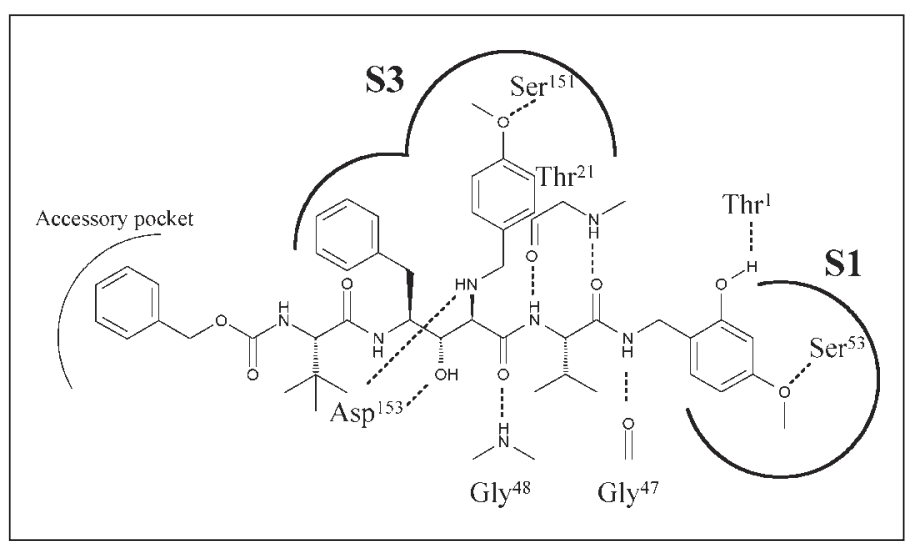

Fig. 2. Schematic representation of the predicted interactions of compound 1 with the chymotrypsin-like active site of the human $20 \mathrm{~S}$ proteasome.
Tyr-133 are involved in a stacking interaction. Extensive SAR studies were directed towards increasing the strength of this interaction or the number of van der Waals contacts. Compounds 2-7 (Table) are representative examples of the derivatives analyzed. Modification of the N-terminal phenyl ring did not affect substantially the inhibitory activities of the compounds and a major effect on potency was only observed for the inhibitors containing bulkier groups and, in particular, naphthyl derivatives. Thus, the replacement of the benzyloxycarbonyl group by naphthalen-1-ylacetic acid improved 9-fold the potency of the starting compound (compound 7 versus 1 in the Table) [6].

A more substantial increase in potency was obtained by optimizing the interaction of the inhibitor with the S3 pocket of the enzyme. According to our model [9], the 2-aminobenzyl group of the statine moiety is involved in two hydrogen bond interactions: one between the nitrogen atom and Asp-153, and the second one between the 4-methoxy substituent of the benzyl group and Ser-151 (Fig. 2). This last interaction was confirmed by the drop in activity observed when a derivative lacking the 4methoxy substituent was tested (compound 8, Table). Examination of the model suggested that two other residues that form the S3 pocket, Ser-157 and Tyr-135, could be targeted for additional hydrogen bond interactions. A methoxy substituent in position 2 or 3 of the benzylamino moiety could accept a hydrogen bond from Ser- 157 while Tyr-135 could donate a hydrogen bond to a methoxy in position 5. Further SAR studies involved the synthesis of mono-, di- and tri-substituted benzylamino derivatives (compounds 9 to 16, Table). Compound 16, which maximizes the number of hydrogen bond interactions in the $\mathrm{S} 3$ pocket, showed a remarkable increase in potency $\left(\mathrm{IC}_{50}=\right.$ $50 \mathrm{nM}$; Table) [10].

Combining the N-terminal naphthalen1-yl-acetic acid with the central 3,4,5trimethoxybenzyl moiety resulted in compound $\mathbf{1 7}$, which is one of the most potent non-covalent inhibitors of the human $20 \mathrm{~S}$ proteasome described to date $\left(\mathrm{IC}_{50}=7 \mathrm{nM}\right.$; Table). These two modifications did not affect the specificity profile of this class of inhibitors. Compound $\mathbf{1 7}$ has a modest activity against the trypsin-like and PGPH activities of the $20 \mathrm{~S}$ proteasome $\left(\mathrm{IC}_{50}>\right.$ $20 \mu \mathrm{M})$ [10]. 


\section{Conclusions}

Early inhibitors of the 20S proteasome have been invaluable tools for improving our understanding of the proteasome degradation pathway in vitro. However, they are relatively non-specific compounds and exert their inhibitory activity by forming a covalent bond with the enzyme. We have identified a new class of non-covalent inhibitors able to modulate the chymotrypsin-like activity of the $20 \mathrm{~S}$ proteasome in ways not previously possible. The increased potency and selectivity of the compounds described in this paper should allow us to investigate and eventually confirm the potential therapeutic application of this approach.

\section{Acknowledgements}

We thank D. Arz, R. Wille, V. von Arx, V. Huy Luu, J.M. Groell, W. Beck, and E. Boss for technical assistance.

Received: February 7, 2003
[1] a) K. Tanaka, J. Biochem. 1998, 123, 195; b) K. Tanaka, M. Kasahara, Immunol. Rev. 1998, 163, 161.

[2] M. Orlowski, C. Cardozo, C. Michaud, Biochemistry 1993, 32, 1563.

[3] For a recent review on 20S proteasome inhibitors, see C. García-Echeverría, $M i$ ni-Reviews in Medicinal Chemistry 2002, 2, 247.

[4] A dipeptide boric acid analogue (PS-341, Velcade $^{\mathrm{TM}}$ ) is currently in Phase III clinical trials for the treatment of multiple myeloma. For preclinical data on this compound, see: J. Adams, V.J. Palombella, E.A. Sausville, J. Johnson, A. Destree, D.D. Lazarus, J. Maas, C.S. Pien, S. Prakash, P.J. Elliott, Cancer Res. 1999, 59, 2615.

[5] Several classes of $20 \mathrm{~S}$ proteasome inhibitors have been described: peptide aldehydes, peptide $\alpha$-keto aldehydes (glyoxals), peptide $\alpha^{\prime}, \beta^{\prime}$-epoxyketones, peptide vinyl sulfones, peptide indanones, peptide boric acids (e.g. PS-341, see [4]), bifunctional inhibitors or natural products (e.g. lactacystin, epoxomicin, TMC-95A-D or UCK 14A2); see also [3].
[6] C. García-Echeverría, P. Imbach, D. France, P. Fuerst, M. Lang, M. Noorani, D. Scholz, J. Zimmermann, P. Furet, Bioorg. Med. Chem. Lett. 2001, 11, 1317.

[7] Other inhibitors of the HIV-1 protease have also been described as inhibitors of the 20S proteasome: a) P. Andre, V. Lotteau, R.M, Zinkernagel, P. Klenerman, M. Groettrup, WO 9963998, 1999; b) P. Andre, M. Groettrup, P. Klenerman, R. de Giuli, B.L. Booth, Jr., V. Cerundolo, M. Bonneville, F. Jotereau, R.M. Zinkernagel, V. Lotteau, Proc. Nat. Acad. Sci. U.S.A. 1998, 95, 13120.

[8] M. Groll, L. Ditzel, J. Löwe, D. Stock, M. Bochtler, H.D. Bartunik, R. Huber, Nature 1997, 386, 463.

[9] P. Furet, P. Imbach, P. Fuerst, M. Lang, M. Noorani, J. Zimmermann, C. GarcíaEcheverría, Bioorg. Med. Chem. Lett. 2001, 11, 1321.

[10] P. Furet, P. Imbach, P. Fuerst, M. Lang, M. Noorani, J. Zimmermann, C. GarcíaEcheverría, Bioorg. Med. Chem. Lett. 2002, 12, 1331 .

\title{
Covalent Labeling of Fusion Proteins with Chemical Probes in Living Cells
}

\author{
Susanne Gendreiziga,b*, Antje Keppler ${ }^{a, b}$, Alexandre Juillerat ${ }^{a, b}$, Thomas Gronemeyer ${ }^{a, b}$, \\ Horst Pick $^{\mathrm{b}}$, Horst Vogel ${ }^{\mathrm{b}}$, and Kai Johnsson ${ }^{\mathrm{a}, \mathrm{b}}$
}

\begin{abstract}
A general method for the specific and covalent labeling of fusion proteins in vivo is described. The approach is based on the unusual mechanism of the human DNA repair protein $0^{6}$-alkylguanine-DNA alkyltransferase, which irreversibly transfers an alkyl group from $\mathrm{O}^{6}$-alkylguanine-DNA to one of its cysteine residues. Labeling is possible in bacterial as well as eukaryotic cells and is independent of the nature of the label, thereby opening up new ways to study proteins in vivo.
\end{abstract}

Keywords: $\mathrm{O}^{6}$-Alkylguanine-DNA alkyltransferase $\cdot$ Fluorescent probes · Protein labeling

*Correspondence: S. Gendreizig ${ }^{a, b}$

Tel.: +41216939442

Fax: +41216939365

E-Mail: susanne.gendreizig@epfl.ch

aswiss Federal Institute of Technology

Lausanne (EPFL)

Institute of Molecular and Biological Chemistry

$\mathrm{CH}-1015$ Lausanne

bSwiss Federal Institute of Technology

Lausanne (EPFL)

Institute of Biomolecular Sciences

$\mathrm{CH}-1015$ Lausanne
Understanding the function of proteins on a molecular level often requires characterizing their location and interaction partners within the living cell. Despite the importance of this task, there are few methods that allow proteins to be studied in vivo. Most existing approaches rely on genetically fusing the protein of interest to a reporter protein that gives the observer a direct or indirect measure of the location and microenvironment of the tagged protein. The most prominent examples for such reporter proteins are fluorescent proteins [1]. However, all currently existing approaches possess various disadvantages and we have recently introduced a general method for the covalent labeling of fusion proteins in vivo that complements the existing strate- 